\title{
PENGARUH ORGANIZATIONAL LEARNING CULTURE TERHADAP EMPLOYEE PERFORMANCE DENGAN JOB SATISFACTION SEBAGAI MEDIASI
}

\author{
Evelyn Angelina dan Yanuar
}

Program Studi Manajemen Fakultas Ekonomi dan Bisnis, Universitas Tarumanagara, Jakarta

Email : evelyn.115170196@stu.untar.ac.id : yanuar@fe.untar.ac.id

\begin{abstract}
This study aims to determine the role of job satisfaction in mediating the relationship between organizational learning culture and employee performance. The subjects studied were the employees at PT XYZ which is an import agent company as well as a complete supplier of factory doors and warehouse needs in Indonesia. The number of samples taken in this study were 85 employees and 15 supervisors who were obtained by distributing questionnaires through google form with Non-probability sampling technique. The collected data is processed using SmartPLS. The results of data processing indicate that organizational learning culture has a positive effect on job satisfaction, job satisfaction has a positive effect on employee performance. However, the function of job satisfaction as a mediating variable in this study was not achieved because the correlation value with mediation is smaller than the value of organizational learning culture which can directly have a positive effect on employee performance. So the employee performance in this study is a partial mediation.
\end{abstract}

Keywords: Organizational Learning Culture, Job Satisfaction, Performance.

Abstrak : Penelitian ini bertujuan untuk mengetahui Peranan Kepuasan Kerja sebagai Mediasi Hubungan antara Budaya Belajar Organisasi dan Kinerja Karyawan. Subjek yang diteliti adalah karyawan pada PT XYZ yang merupakan perusahaan agen import serta penyedia pintu pabrik dan kebutuhan gudang secara lengkap di Indonesia. Jumlah sampel yang diambil pada penelitian ini adalah karyawan dengan jumlah 85 orang dan supervisor 15 orang yang diperoleh dengan menyebar kuesioner melalui google form dengan teknik pengambilan sampel jenuh/sensus. Data yang telah dikumpulkan diolah menggunakan SmartPLS. Hasil dari pengolahan data menunjukkan bahwa budaya belajar organisasi berpengaruh positif terhadap kepuasan kerja, kepuasan kerja berpengaruh positif terhadap kinerja karyawan. Namun, fungsi kepuasan kerja sebagai variabel mediasi pada penelitian ini tidak tercapai karena nilai kolerasi dengan adanya mediasi lebih kecil daripada nilai budaya belajar organisasi yang secara langsung dapat berpengaruh positif terhadap kinerja karyawan. Maka kinerja karyawan disini merupakan mediasi parsial.

Kata kunci: Budaya Belajar Organisasi, Kepuasan Kerja, Kinerja Karyawan

\section{LATAR BELAKANG}

Studi mengenai Sumber daya Manusia saat ini cukup populer seperti dilihat dari karya oleh para peneliti (Jayathilake et al., 2021) yang membahas organizational learning culture \& job satisfaction tentang esensi, peranan, proses dan bentuk orientasi Sumber Daya Manusia yang dilakukan untuk meningkatkan kinerja karyawan (Robbins dan Judge, 2013). (Singh et al., 2013) telah mengidentifikasi bahwa praktik MSDM pengembangan karyawan sebagai 
kegiatan operasional organisasi atau alat yang dapat menciptakan nilai-nilai sebagai pemicu untuk memenuhi kebutuhan aktualisasi diri karyawan. Berdasarkan pendapat (Fake dan Dabbagh, 2020) Kinerja karyawan begitu penting dan berpengaruh bagi keberlangsungan dan berjalannya perusahaan atau organisasi.

Walaupun banyak faktor yang mempengaruhi kinerja karyawan namun dalam studi (Hendri, 2019) menemukan bahwa hasil analisis menunjukkan budaya belajar organisasi tidak berpengaruh signifikan terhadap kinerja karyawan, tidak seperti studi yang dilakukan Sahoo, S. (2021) yang menyatakan bahwa budaya belajar organisasi berpengaruh terhadap kinerja karyawan. Oleh karena itu, muncul pertanyaan kritis mengenai apa yang harus ada agar orientasi budaya belajar organisasi mampu meningkatkan kinerja karyawan. Setelah dilakukannya survey dan pengamatan oleh peneliti, adapun fenomena berkurangnya kinerja karyawan berdasarkan survey pada perusahan selama tiga tahun terakhir sebagai berikut :

Tabel 1.1

Penilaian Kinerja Karyawan pada PT XYZ

\begin{tabular}{|cccc|}
\hline KPI & $\mathbf{2 0 1 8}$ & $\mathbf{2 0 1 9}$ & $\mathbf{2 0 2 0}$ \\
\hline Performance & $69,17 \%$ & $67,45 \%$ & $64,16 \%$ \\
\hline Competence & $17,78 \%$ & $17,72 \%$ & $17,63 \%$ \\
\hline Human Resource Development & $10 \%$ & $9,96 \%$ & $9,94 \%$ \\
\hline Total & $96,95 \%$ & $95,13 \%$ & $91,73 \%$ \\
\hline
\end{tabular}

Sumber: Dokumentasi Perusahaan

Presentase kinerja pada karyawan PT XYZ dinilai berdasarkan Key Performance Indicator (KPI) yang ada pada perusahaan. Besarnya penurunan yang ada dapat terlihat cukup jelas dari tahun ke tahun. Hal ini dipercaya disebabkan oleh tingkat inisiatif karyawan untuk mengembangkan dan mempertahankan kemampuan dan minat kerja masih cukup rendah dipengaruhi oleh penerapan budaya dan pembelajaran organisasi pada perusahaan kurang optimal sehingga berpengaruh terhadap perkembangan kinerja mereka. Disamping itu, keadaan / lingkungan kerja dari tahun ke tahun di tempat kerja seringkali berubah, begitu pula yang terjadi pada perusahaan dari tahun 2018 - 2020.

Hal tersebut mendorong peneliti untuk menjadikan karyawan pada PT XYZ ini sebagai objek penelitian pada penelitian ini yang mana merupakan sebuah perusahaan agen import serta penyedia pintu pabrik dan kebutuhan gudang secara lengkap di Indonesia.

\section{KAJIAN TEORI}

\section{Teori Manajemen Sumber Daya Manusia}

Menurut (Dessler, 2011:5) Manajemen Sumber Daya Manusia adalah kebijakan dan praktik menentukan aspek manusia atau sumber daya manusia dalam posisi manajemen, termasuk merekrut, menyaring, melatih, memberi penghargaan, dan penilaian serta mengatur hubungan dan peranan tenaga kerja agar aktif dan efisien dalam menggunakan kemampuan manusia dalam membantu terwujudnya tujuan perusahaan. Masih menurut Menurut (Dessler, 2015:3), manajemen sumber daya manusia adalah proses untuk memperoleh, melatih, menilai, dan mengompensasi karyawan dan untuk mengurus relasi tenaga kerja, kesehatan dan keselamatan, serta hal-hal yang berhubungan dengan keadilan. 


\section{Teori Social Exchange}

Perlunya memaksimalkan kinerja karyawan agar MSDM dapat berjalan efektif yang dapat ditinjau melalui "social exchange theory" yang dikembangkan oleh (Blau, 1964). Dalam teori ini dinyatakan, karyawan akan mengembangkan kualitas hubungan berdasarkan pada siapa dan bagaimana mereka berinteraksi serta bagaimana pengalaman kerja mereka (Blau, 1964; Cropanzano dan Mitchell, 2005).

\section{Maslow's Hierarchy of Needs Theory}

Sistem hirarki kebutuhan yang dikembangkan oleh Maslow, merupakan pola yang biasa digunakan untuk menggolongkan motif manusia. Sistem hirarki kebutuhan meliputi lima kategori motif yang disusun dari kebutuhan yang paling rendah yang harus dipenuhi terlebih dahulu sebelum memenuhi kebutuhan yang lebih tinggi (Wallace, Goldstein dan Nathan, 2007: 277). Kelima tingkat kebutuhan sebagaimana diuraikan oleh (Hamner dan Organ, 2005: 138) ditunjukkan dalam tingkatan kebutuhan berikut:

1. Kebutuhan Fisiologis

2. Kebutuhan Rasa aman

3. Kebutuhan Sosial

4. Kebutuhan Harga Diri

5. Kebutuhan Aktualisasi Diri

\section{Teori Organizational Learning Culture}

OLC merupakan salah satu komponen kontekstual untuk meningkatkan kepuasan karir, didasarkan pada keterampilan organisasi dalam menciptakan, memperoleh, dan mentransfer pengetahuan dan dalam memodifikasi perilaku untuk mencerminkan pengetahuan dan wawasan baru (Joo dan Ready, 2012). OLC mencakup kumpulan konvensi, nilai, sikap, dan praktik organisasi yang mendorong pembelajaran berkelanjutan dan pengembangan profesional (Dessler, 2015).

\section{Teori Job Satisfaction}

Kepuasan kerja adalah kondisi emosional yang menyenangkan yang disebabkan oleh penilaian pribadi terhadap kondisi kerja dan pengalaman kerja individu dalam organisasi (Kinicki dan Kreitner, 2005). Kepuasan kerja dapat digambarkan sebagai reaksi afektif dan kognitif karyawan terhadap pekerjaannya di tempat kerja (Robbins dan Judge, 2013).

\section{Teori Employee Performance}

Kinerja merupakan fungsi dari kemampuan interaksi, motivasi, dan kesempatan untuk tampil (Yanuar, 2017). Berkembangnya tenaga kerja yang sangat terampil dan berkinerja tinggi menyebabkan perkembangan daya saing (Dessler, 2011). Prestasi kerja menyangkut dirinya dengan hasil tugas yang diselesaikan oleh karyawan. Dalam arti lebih lanjut berkaitan dengan standar kerja yang berkorelasi dengan kualitas luar biasa dan produktivitas (Yanuar et al., 2019) 


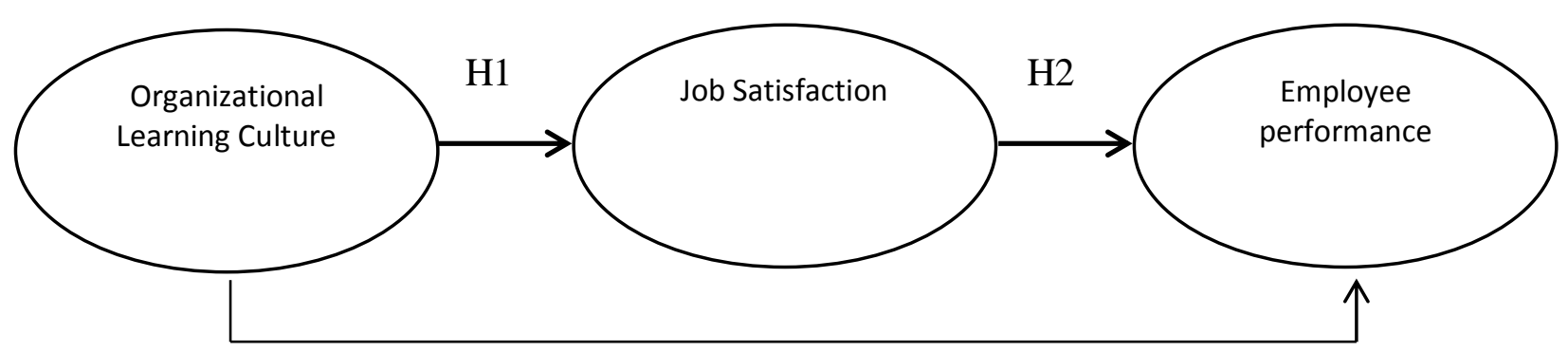

$\mathrm{H} 3$

Gambar 1.

Model Penelitian

\section{Hipotesis}

H1 : Budaya belajar organisasi berpengaruh positif terhadap kepuasan kerja.

H2 : Kepuasan kerja berpengaruh positif terhadap kinerja karyawan.

H3 : Budaya belajar organisasi berpengaruh positif terhadap kinerja karyawan dengan kepuasan kerja sebagai variabel mediasi.

\section{METODOLOGI}

Pada penelitian ini menggunakan metode penelitian deskriptif yaitu menyebarkan sejumlah kuesioner yang dibagikan pada karyawan dari perusahaan dan menggunakan pendekatan kuantitatif. Populasi dari penelitian ini adalah karyawan PT XYZ. Sampel yang digunakan untuk penelitian ini adalah karyawan yang bekerja pada perusahaan sebanyak 85 orang beserta 15 supervisor. Non Probability Sampling, teknik sampling jenuh (sensus) digunakan sebagai teknik pemilihan sampel yang ditentukan jika semua anggota populasi digunakan sebagai sampel. Penelitian ini menggunakan Structural Equation Modeling (SEM) dimana menurut (Hair et al., 2013) dengan SEM ini memungkinkan untuk membuat analisis terhadap serangkaian hubungan yang dilakukan untuk mendapatkan hasil data yang lebih efisien secara statistik.

Pengukuran variabel-variabel dalam penelitian ini mengacu pada penelitian sebelumnya antara lain sebagai berikut:

\begin{tabular}{|c|c|c|}
\hline Variabel & Indikator & Acuan \\
\hline Organizational learning Culture & 5 Item & (Fake and Dabbagh, 2020) \\
\hline Job Satisfaction & 5 Item & (Hendri, 2019) \\
\hline Employee Performance & 7 Item & (Jerome, 2013) \\
\hline
\end{tabular}

\section{HASIL ANALISIS DATA}

Analisis validitas, baik convergent validity maupun discriminant validity, telah dilakukan dengan menggunakan analisis average variance extracted, loading factors, dan cross loading. Hasilnya seluruh variabel dan indikator dalam penelitian ini valid untuk 
digunakan. Ketiga variabel yang digunakan dalam penelitian ini juga dinyatakan reliabel, karena memiliki nilai composite reliability diatas 0,70 dan nilai cronbach's alpha diatas 0,60 (Hair et al., 2013:123).

Berdasarkan hasil uji koefisien determinasi (R2), sebesar 91,2\% variabel employee performance (employee) dipengaruhi secara kuat oleh variabel job satisfaction, Sebesar 77,2\% variabel employee performance (supervisor) dipengaruhi secara kuat oleh variabel job satisfaction, dan 83,9\% variabel Job Satisfaction dipengaruhi secara kuat oleh variabel organizational learning culture. Berdasarkan hasil pengujian di atas dapat disimpulkan bahwa nilai $R$-Square dalam penelitian ini tergolong substansial (kuat) (Hair et al., 2013: 161). Sedangkan hasil uji predictive relevance (Q2) yang dihasilkan oleh konstruk penelitian sebesar 0,718 pada job satisfaction, pada employee performance (employee) adalah sebesar 0,747 , dan pada employe performance (supervisor) adalah sebesar 0,644 yang berarti hasilnya relevan karena Q2 memiliki nilai > 0 (Hair et al., 2013: 98-99).

Tabel 1. Hasil Uji Hipotesis

\begin{tabular}{|c|c|c|c|}
\hline Variabel & $\begin{array}{c}\text { Path } \\
\text { Coefficients }\end{array}$ & t-statistics & $\boldsymbol{p}$-values \\
\hline Job Satisfaction -> Employee Performance & 0,320 & 4,278 & $\mathbf{0 , 0 0 0}$ \\
\hline $\begin{array}{c}\text { Organizational Learning Culture -> Employee } \\
\text { Performance }\end{array}$ & 0,653 & 8,855 & $\mathbf{0 , 0 0 0}$ \\
\hline $\begin{array}{c}\text { Organizational Learning Culture -> Job } \\
\text { Satisfaction }\end{array}$ & 0,916 & 29,696 & $\mathbf{0 , 0 0 0}$ \\
\hline $\begin{array}{c}\text { Organizational Learning Culture -> Job } \\
\text { Satisfaction -> Employee Performance }\end{array}$ & 0,293 & 4,175 & $\mathbf{0 , 0 0 0}$ \\
\hline
\end{tabular}

Berdasarkan nilai bootstraping pada path coefficients maka diketahui bahwa H1 yang menyatakan Organizational Learning Culture berpengaruh positif terhadap Job satisfaction diterima karena menghasilkan nilai original sample sebesar 0,916>0,t-statistics 29,696 $>1,96$, dan $p$-values $0,000<0,05$ yang berarti berpengaruh signifikan.

Hasil H2 menyatakan Job Satisfaction berpengaruh positif terhadap employee performance karena original sample sebesar 0,320 > 0, t-statistics 4,278 > 1,96 dan p-values $0,000<0,05$ yang berarti berpengaruh signifikan.

Kemudian $\mathrm{H} 3$ yang menyatakan organizational learning culture berpengaruh positif terhadap employee performance dengan job satisfaction sebagai variabel mediasi dengan original sample sebesar $0,293>0, t$-statistics $4,175>1,645$ dan $\mathrm{p}$-values $0,000<0,05$ yang berarti berpengaruh positif.

Namun, jika dilihat kembali dari hasil bootstraping pada tabel 4.17 nilai kolerasi organizational learning culture -> employee performance adalah 0,653 dimana nilai tersebut lebih besar dibandingkan dengan nilai kolerasi setelah adanya variabel mediasi organizational learning culture -> job satisfaction -> employee performance yaitu 0,293. Dengan diterimanya hipotesis ketiga, walaupun kepuasan kerja mampu meningkatkan kinerja karyawan namun kepuasan kerja dari budaya berlajar organisasi tidak mempunyai pengaruh besar terhadap kinerja karyawan. Hal ini didasarkan oleh data hasil kuesioner yang telah diisi masing-masing responden, mereka merasa puas dengan budaya belajar pada perusahaan, namun rasa kepuasan tersebut bukanlah hal utama yang memicu berkembangnya kinerja karyawan karena budaya belajar organisasi yang diterapkan oleh perusahaan lebih dapat secara langsung mempengaruhi 
kinerja karyawannya menjadi lebih baik. Maka dari itu, pada penelitian kali ini fungsi mediasi dari kepuasan kerja untuk memperkuat hubungan antara budaya belajar organisasi dan kinerja karyawan tidak tercapai. Kepuasan kerja disini merupakan partial mediation karena ada atau tidaknya variabel mediasi ini, variabel independen akan tetap dapat berpengaruh positif terhadap variabel dependen secara langsung.

\section{DISKUSI}

Dengan diterimanya $\mathrm{H} 1$, apabila semakin tinggi budaya belajar organisasi yang dirasakan karyawan kepuasan kerja karyawan juga akan semakin meningkat. Budaya belajar organisasi bagi karyawan merupakan peranan penting sehingga bisa berdampak pada sikap karyawan terhadap perusahaan. Dengan budaya belajar organisasi yang baik, karyawan akan merasa terdorong dalam bekerja sehingga adanya tingkat kepuasan dalam bekerja. Hasil penelitian ini sesuai dengan hasil penelitian (Hendri, 2019) yang menyatakan bahwa OLC sebagai pendorong anggota organisasi untuk terus belajar sehingga berpengaruh positif dengan kepuasan kerja karyawan. Kemudian, hasil penelitian (Sahoo, 2021) yang mengemukakan bahwa budaya belajar organisasi berkaitan positif dengan kepuasan kerja. Terakhir, hasil penelitian dari (Soomro dan Shah, 2019) yang menyatakan bahwa terdapat pengaruh positif signifikan budaya belajar organisasi terhadap kepuasan kerja.

Dengan diterimanya $\mathrm{H} 2$, karyawan dengan tingkat kepuasan kerja yang tinggi akan mempengaruhi kinerjanya. Hasil penelitian ini sesuai dengan hasil penelitian (Tran, 2021) menyatakan bahwa kepuasan kerja berkaitan dengan kondisi emosional yang menyenangkan sebagai pendorong karyawan yang berpengaruh positif dengan kinerja karyawan yang lebih baik. Kemudian, hasil penelitian (Yan Li et al., 2019) menyatakan karyawan yang puas dengan pekerjaannya memberikan kinerja yang lebih tinggi daripada karyawan yang tidak puas. Hal ini menunjukkan bahwa kepuasan kerja memberikan kontribusi positif terhadap kinerja karyawan.

Dengan diterimanya H3, walaupun kepuasan kerja mampu meningkatkan kinerja karyawan PT XYZ namun kepuasan kerja yang didapat dari budaya berlajar organisasi tidak mempunyai pengaruh besar terhadap kinerja karyawan. Hal ini didasarkan oleh data hasil kuesioner yang telah diisi masing-masing responden, mereka merasa puas dengan budaya belajar pada perusahaan, namun rasa kepuasan tersebut bukanlah hal utama yang memicu berkembangnya kinerja karyawan karena budaya belajar organisasi yang diterapkan oleh perusahaan lebih dapat secara langsung mempengaruhi kinerja karyawannya. Dengan kata lain, fungsi mediasi dari kepuasan kerja untuk memperkuat hubungan antara budaya belajar organisasi dan kinerja karyawan tidak tercapai. Hasil penelitian ini tidak sesuai dengan hasil penelitian (Park and Doo, 2020) yang mengatakan bahwa budaya belajar organisasi memiliki pengaruh langsung terhadap kinerja karyawan, tetapi pengaruhnya bersifat lemah dan harus menambahkan variabel kepuasan kerja sebagai variabel mediasi agar hubungannya semakin kuat. Namun sesuai dengan hasil penelitian dari (Jayathilake et al., 2021) bahwa, budaya belajar organisasi sendiri sudah memiliki potensi dampak yang signifikan pada peningkatan pengembangan karyawan yang dapat berdampak pada pencapaian kinerja organisasi yang lebih baik. Sehingga ketika variable kepuasan kerja ditambahkan sebagai varibel mediasi maka pengaruhnya bersifat parsial seperti pada penelitian (Devonish, 2018), karena ada atau tidaknya variabel kepuasan kerja sebagai mediasi, variabel budaya belajar organisasi akan tetap berpengaruh secara positif terhadap variabel kepuasan kerja. 


\section{PENUTUP}

Berdasarkan hasil dari penelitian dan penjelasan yang telah dilakukan atas penelitian organizational learning culture terhadap employee performance dengan job satisfaction sebagai variabel mediasi bahwa Hipotesis satu (H1) adalah organizational learning culture mempunyai pengaruh terhadap job satisfaction, artinya peningkatan dari organizational learning culture menyebabkan karyawan mengalami job satisfaction dalam pekerjaan. Hipotesis dua $(\mathrm{H} 2)$ adalah dengan adanya job satisfaction, dapat berpengaruh untuk meningkatkan employee performance di perusahaan. Pada Hipotesis tiga (H3) berdasarkan hasil dari data kuesioner yang telah diisi oleh masing-masing responden menyatakan bahwa fungsi mediasi dari job satisfaction untuk memperkuat hubungan antara organizational learning culture dan employee performance tidak tercapai dikarenakan oleh nilai kolerasi antara variabel independen ke dependen secara langsung lebih besar dibandingkan oleh nilai dengan adanya variabel mediasi.

Bagi perusahaan, disarankan untuk meningkatkan penerapan organizational learning culture kepada karyawan baik dengan adanya faktor dari job satisfaction sebagai variabel mediasi atau tidak agar semakin dapat meningkatkan employee performance secara berkala. Karena meskipun pada hasil statistik penelitian untuk peran faktor mediasi tidak tercapai tetapi masih banyak penelitian terdahulu dan teori lain yang mendukung bahwa job satisfaction dapat meningkatkan employee performance dengan variabel lainnya.

Saran untuk peneliti selanjutnya Bagi peneliti selanjutnya disarankan untuk menambah variabel-variabel baru selain variabel organizational learning culture dan job satisfaction, karena tujuan job satisfaction sebagai variabel mediasi pada penelitian ini tidak tercapai dalam mempengaruhi employee performance. Sehingga diperlukannya variabel baru yang mungkin dapat menekan angka employee performance secara signifikan.

\section{DAFTAR PUSTAKA}

Baek-Kyoo (Brian) Joo, Kathryn J. Ready, (2012). Career satisfaction: The influences of proactive personality, performance goal orientation, organizational learning culture, and leader-member exchange quality. Career Development International. 17(3), 276 - 295

Blau, P.M. (1964). Exchange and power in social life. New York: Wiley \& Sons.

Cropanzano, R. and Mitchell, M.S. (2005). Social exchange theory: an interdisciplinary review. Journal of Management, 31(6), 874- 900.

Dessler, G. (2011). Human Resource Management. 12th Edition. New Jersey: Pearson Prentice Hall.

Dessler, G. (2015). Fundamentals of Human Resource Management. 4th Edition, Global Edition, Pearson International.

Devonish, D. (2018). Effort-reward imbalance at work: the role of job satisfaction. Personnel Review. 47(2), 319-333. doi:10.1108/PR-08-2016-0218

Fake, H. and Dabbagh, N. (2020). Personalized learning within online workforce learning environments: exploring implementations, obstacles, opportunities, and perspectives of workforce leaders, Technology, Knowledge and Learning. 25, 789-809.

Hair, J. \& et al. (2013). Multivariate Data Analysis (7th ed.). Pearson Education Limited.

Hamner, W. Clay and D. Organ, (2005). Organizational Behavior. Dallas: Business Publ cations.

Hendri, M.I. (2019). The mediation effect of job satisfaction and organizational commitment on the organizational learning effect of the employee performance. International 
Journal of Productivity and Performance Management. 68(7), 1208-1234. Publisher: Emerald Publishing Limited.

Jayathilake, H.D., Daud, D., Eaw, H.C. and Annuar, N. (2021). Employee development and retention of Generation-Z employees in the post-COVID-19 workplace: a conceptual framework. Benchmarking: An International Journal. doi:10.1108/BIJ-06-2020-0311

Jerome, N. (2013), Application of the Maslow's hierarchy of need theory; impacts and implications on organizational culture, human resource and employee's performance. International Journal of Business and Management Invention. 2(3), 39-45.

Kinicki, Angelo and R. Kreitner, (2005). Organizational Behavior Key concepts skills and best Practice. Mc Graw-Hill, New York, hal. 125.

Li, Y., Mehmood, K., Zhang, X. and Crossin, C.M. (2019). A Multilevel Study of Leaders' Emotional Labor on Servant Leadership and Job Satisfaction. Emotions and Leadership (Research on Emotion in Organizations). 15, Emerald Publishing Limited, Bingley, 4767. doi:10.1108/S1746-979120190000015008

Park, S. and Doo, M.Y.(2020). The effect of organizational culture and HR practices on female managers' commitment and job satisfaction. European Journal of Training and Development. 44(2/3), 105-120. doi:10.1108/EJTD-03-2019-0045

Robbins, S.P. and Judge, T.A. (2013). Organisational Behavior (15th ed.). Boston: Pearson.

Sahoo, S. (2021). Lean practices and operational performance: the role of organizational culture. International Journal of Quality \& Reliability Management. doi:10.1108/IJQRM-03-2020-0067

Singh, S., Kodwani, A.D. and Agrawal, R.K. (2013). Role of lifestyle orientation and perceived organizational functioning in psychological empowerment of IT professionals. Benchmarking: An International Journal. 20(3), 396-418.

Soomro, B.A. and Shah, N. (2019). Determining the impact of entrepreneurial orientation and organizational culture on job satisfaction, organizational commitment, and employee's performance. South Asian Journal of Business Studies. 8(3), 266282. doi:10.1108/SAJBS-12-2018-0142

Tran, Q.H.N. (2021). Organisational culture, leadership behaviour and job satisfaction in the Vietnam context. International Journal of Organizational Analysis. 29(1), 136154. doi:10.1108/IJOA-10-2019-1919

Wallace, Patricia, Jeffrey H. Goldstein, Peter Nathan, (2007). Introduction to Psychology. Dubuque, IA: Wm. C. Brown.

Yanuar. (2017). Compensation, Motivation and Performance of Employees: Evidence from Indonesia. International Journal of Economic Perspectives. 2017,11(4), 486-492.

Yanuar, Yenny, L., Ronnie, R.M.. (2019). Job Performance and Government Banks: Evidence from Indonesia. International Journal of Innovation, Creativity and Change. www.ijicc.net, 6(11), 2019. 